THE ECOLOGICAL RELATIONS OF THE VEGETATION ON THE SAND DUNES OF LAKE MICHIGAN.

Henry Chander Cowles.

[Continued from p. 117.]

\title{
3. The upper beach.
}

In the strictest sense the upper beach is not a portion of the beach at all, since it is beyond the reach of the waves; it might perhaps be called a fossil beach, but the fact that it is continuous with the beach proper seems to exclude that term, as does the recency of its fossilization. The expression fossil beach will be reserved for a formation of greater geological age and separated from the present beach by other topographic forms. Where dunes are superposed upon the beach, the upper limits of this third beach zone are quite vague, though the theoretical line of demarcation is where the sand is first accumulated by the wind. Where clay bluffs are present at the water's edge, the beach is quite narrow and the upper limit fairly well defined, though at times obscured by alluvial fans. Occasionally the upper beach approaches very close to the water's edge; this is the case a high gradient. Sometimes the lower or middle beach zone is replaced by a tiny cliff; in such a case the upper beach may beach, as to the edge of this cliff. The limits of the upper lower limits of other beach zones, are constantly shifting. The winter storms, butried lakeward or landward by the waves of more and more lo but on the whole the lower limits are pushed out lower beach lakeward, keeping pace with the advance of the upper limits, The shifting of the wind causes variations in the formed more and on the whole the dunes likewise are commonly The three beaches, more lakeward, as will be shown further on. irregularity, but thes, then, shift from year to year with apparent ${ }_{1899}$ ] 
gressive movement of them all out into the lake. As a whole the three beach zones slope gradually and somewhat evenly upward, toward the dunes or bluffs beyond; depressions, however, are not at all uncommon, and at times they reach down to the water level, so that a beach pool results.

The life conditions are much less severe than on the middle beach, and chiefly because of the freedom from the wave action of the winter storms. The exposure to the sun is almost as great as on the lower zones, but there is more protection from the wind because of the abundance of driftwood. The protective influence exerted by piles of débris is finely shown on the beach at North Manitou island. The upper beach along the south shore of the lake is usually very sandy and comparatively free from driftwood, while the North Manitou beaches are composed chiefly of gravel and shingle with heaps of driftwood piled about in the greatest confusion. The North Manitou flora is one of marked luxuriance, compared with the more southern type, and many mesophytic species are able to get a foothold in the more genial conditions there obtaining. The decay of the drittwood may also add no inconsiderable portion to the food materials of the beach plants.

The flora of the upper beach is much richer than that of the middle beach, both in species and in individuals, but here 25 there the vegetation is so sparse that the tone to the landscape is given by the soil. In the region as a whole the most characteristic species of the upper beach are Artemisia caudata and A. Canadensis. ${ }^{\mathbf{2}}$

At nearly all places visited between Chicago and Beaver island Artemisia was present and commonly in abundance. Another plant associated almost everywhere with Artemisia is Cnicus Pitcheri; this thistle is seldom so common as Artemisia, but scattered specimens are pretty sure to be discovered on any

${ }^{x}$ Typical forms of both Artemias gradations, and it is all but hopeless have been found, as wich is the more abundast without careful examination of all the plants in time of fruit. Both species are pube cent in beach and dune habitats, although $A$. Canadensis is the more so. 
upper beach. A species scarcely less important in this connection is the beach pea, Lathyrus maritimus, another marine plant; locally the beach pea is often the dominant character plant, especially northward. Three other species are character plants over wide areas, as the above three are throughout. Euphorbia polygonifolia is a character plant at many stations between Chicago and Glen Haven; its absolute abundance is often as marked on the upper as on the middle beach, though its relative importance is much greater on the latter. Agropyrum dasystachyum and Enothera biennis are as characteristic of upper beaches northward as Euphorbia is southward; Agropyrum especially is usually a dominant character plant north of Glen Haven.

None of the above six species are confined to the upper beach. Artemisia is found in most dune societies inland, especially in comparatively naked places. Cnicus is frequent on the dune complex, though less abundant than on the beach, as is also true of Artemisia. Lathyrus appears to be more restricted in its habitat, and in that sense is more typical of the upper beach, though it sometimes occurs on clay bluffs. Euphorbia occurs on the middle beach and also on naked dunes, though less frequently. Agropyrum, though characteristic of northern upper beaches, is still more characteristic of the embryonic dunes. Enothera occurs on oak dunes and commonly also as a mesophyte.

At this point it will be well to emphasize one of the fundamental principles of ecological plant groupings. It is comparatively seldom that any single species can be regarded as perfectly characteristic of a formation, while a group of five or ten species can be so selected as to enable one to detect that formation almost anywhere within a large area. No one of the above six species can be regarded as perfectly typical of the
upper bed upper beach, although Lathyrus approaches such a type, but together they form an assemblage that cannot be found in any other formation, except perhaps locally on the closely related upper beach, the Even on these beach dunes, which grade into the uper beach, the relative proportions existing between the above 
species are very different from those found on the beach, and, as will be shown later, plant species occur on these dunes which are absent from the beach altogether.

Of the six chief character species of the upper beach, three (Enothera, Artemisia, Cnicus) are commonly biennials, Euphorbia is an annual, while Lathyrus and Agropyrum are perennials with decidedly social habits through extensive rhizome proparation. Thus the perennial habit is much less common on the upper beach than on the dunes. The three biennials pass through the winter in the form of ground rosettes, tall shoots being sent up in the spring. Cnicus has a noteworthy protective covering of woolly hairs.

There are several plant species very characteristic of the embryonic dunes on the beach, which also occur on the upper beach proper, though rarely in great abundance. Notable among these plants are Ammophila arundinacea, and Elymus Canadensis. Ammophila occurs about equally throughout, while Elymus is much more characteristic northward; indeed on the northern upper beaches Elymus is sometimes as abundant 25 Agropyrum or Artemisia. About Chicago Elymus is a common character plant of the dunes, but rarely of the beach. Between Chicago and Muskegon Asclepias Cornuti is a frequent tenant of the upper beach. Calamagrostis longifolia, one of the chief character plants of the active dunes, is sometimes found on the beach, as are Solidago humilis Gillmani (plants large, but leaves not sharply toothed) and Lithospermum hirtum, which are more characteristic of rejuvenated dunes, fossil beaches, and heaths. Cakile Americana and Corispermum hyssopifolium occur but are less abundant than on the middle beach, although the latter is sometimes a prominent upper beach type. The forms discussed in this paragraph are perennials, with the exception of the last tro: as they are all of secondary importance, in reality representing the vanguards of a flora which is more at home farther inland, there seems no necessity for any further defense of the ides that the upper beach flora is not typically composed of perent
nials. 
All of the species discussed up to this time are herbs, passing the winter near the surface of the soil or underneath it. The exposure to which shrubs and trees are subjected during the winter is so severe on the upper beach that few of the many dune species have representatives there. The individual shrubs which brave these conditions are relatively scattered, while the plant body is stunted and bears signs of the severe environment provided by the beach. Much the commonest shrub, and the only one which occurs throughout, is Prunus pumila, the sand cherry. Poplars occasionally occur, Populus monilifera southward and Populus balsamifera (both the type and var. candicans) northward; so too, the willows, Salix glaucophylla, adenophylla, and longifolia.

The most striking feature of the plant life on the upper beach is the difference in its development at different localities. The luxuriant flora of the north is in marked contrast to the impoverished flora at the south end of the lake. The Dune Park beach, for example, is tenanted only by Artemisia, Cnicus, Corispermum, and a few scattering plants of other species. An upper beach on North Manitou island showed a great abundance of Elymus, Artemisia, Lathyrus, Enothera, and Populus balsamifera, together with thirty-four other species which were rare to frequent. Among these other species several are of considerable interest: Anemone multifida, which also occurs on the beach at Beaver island and on several fossil beaches; Prenanthes alba, common in woods and thickets but seemingly out of place on the beach; Equisetum hyemale, which grows almost anywhere. On similar beaches at Empire, Achillea Millefolium and Equisetum arvense, two plants which never grow on the beach farther south, are very abundant. Arabislyrata and Polygonumramosissimum (?) ${ }^{2}$, the former growing on the inland oak dunes about Chicago, occur Th an exposed upper beach at the north end of Beaver island.
beaches are for this great luxuriance of the northern upper beaches are not obvious. It has been previously stated that the greater abundance of driftwood on the more northern beaches ${ }^{2}$ A remarkable dwarf Polygonum with six stamens, very different from the type. 
adequate to account for the great differences, and it may be that climatic or other less apparent factors may have to be called upon. The luxuriance of the northern forests as compared with those about Chicago may need in part a similar explanation.

Interesting beach conditions are to be found on some small islands that have recently formed on reefs in the vicinity of Beaver island. During the winter and spring blocks of ice laden with stones are stranded on these reefs; thus they are gradually built up to the lake level. Wave action comminutes the reef materials forming a soil suitable for plant life; the waves and winds also constantly add to the area of the islands. One such island is about 200 meters in length, five or ten meters in width, and scarcely thirty centimeters high. The flora of this unpro tected island is a swamp flora, $i . e$., the island is in its entiretya hydrophytic beach. Another island, somewhat larger and considerably older, has an altitude of one or two meters at its high. est point. The beach toward the southeast, east, and northeast is hydrophytic, while that toward the northwest, west, and southwest is xerophytic. Undoubtedly the degree of exposure to the wind is the chief cause which determines the nature of the flora on this island. Not only is the wind more severe on the west beach, but the waves pile up more sand on that side of the island and hence produce a drier soil. The flora on this xerophytic upper beach is remarkably complete and diversified, showing a distinct zonal distribution. Above the middle beach there is a zone characterized by the dominance of Elymus Canadensis, then a zone of Geranium Robertianum, then a zone of Artemisia Cant. densis, and findlly a zone in which Cornus stolonifera (or C. Bailer) into which it grades) is the chief character plant. Scattered more or less with these are Prunus pumila, Enothera biennis, Lathy rus maritimus, Cnicus Pitcheri, Agropyrum dasystachyum, and Pops. lus balsamifera. Pastinaca sativa and Geranium Robertianum are common here, and are remarkable inhabitants of a xerophytic beach, since both are usually inland mesophytes. Two other plants occur on this beach that are south of their chief range and rare in the Lake Michigan region, Tanacetum Huronense and 
Anemone multifida. The flora of this isolated island beach is remarkably prolific; scarcely a single upper beach type is absent. It is obvious that the means of plant dispersal are so uniformly successful, that almost an entire flora may be transported to a newly formed island within a few years.

One other common feature of upper beaches should be mentioned. As noted above, there are irregularities in the slope of the beach often resulting in depressions which reach below the water level. Such depressions may be called beach pools and of course have a hydrophytic flora; this flora, however, is not the flora of a hydrophytic beach. Beach pools are relatively protected from the action of winds and waves; the chief difference from a hydrophytic beach is that the latter is washed by the fresh waters of the lake, while the beach pools are far less constantly supplied with fresh water. The conditions in the latter approach somewhat those of the ill-drained inland sloughs between the sandy ridges. By far the most characteristic plant about the pool margins is Juncus Balticus littoralis; this species is more xerophytic than most of its genus, and often creeps well up on the xerophytic upper beach. Triglochin maritima, Potentilla Anserina and several species of Salix also occur about the margins of the pools.

\section{Fossil beaches.}

In regions where dunes are superposed upon the beach, portions of the beach may remain unoccupied by the wind-blown sand, appearing as islands in a sea of dunes. Or a beach which has been covered by the dune-complex may later be uncovered, exposing the gravel and shingle of an ancient shore. In any case these ancient or fossil beaches, separated as they are from the present beach by dunes, are more highly protected from the wind than the beaches which have been previously described. the gradual slopes of an ordinary beach, but their force is considerably broken by a line of dunes. Fossil beaches which have been uncovered by the dune complex occur at Dune Park, but to such a limited extent that a typical flora is not developed. 
The most extensive fossil beach observed was at Glen Haven, where an area several hectares in extent has been denuded of its covering of sand to help supply the extensive dune complex. Similar but smaller fossil beaches were seen at Saugatuck and North Manitou island. Associated with the fossil beach is a formation which may not represent a beach at all. In the general description of the region, reference was made to the high terrace-like bluffs along the northern portions of the lake shore. These miniature plateaux, from which former sand dunes have doubtless been removed, exhibit a surface of gravel, which produces the appearance of a fossil or a true beach. The most extensive of these flat gravel-topped hills are at Glen Haven; similar but less extensive formations of this type were seen at Frankfort and North Manitou island.

The floras of the fossil beaches and the gravel terraces 120 meters above the present beach are essentially identical, although the latter apparently have a greater exposure. Both the beaches and terraces have a flora which resembles that of the upper beach in a general way, but there is a pronounced decrease of most of the typical beach forms and a pronounced increase of the more inland types. Thus the flora clearly illustrates the greater protection from exposure which is enjoyed on the fossil beach. The Artemisias are as characteristic of the fossil beaches and terraces as of the upper beach, but none of their five chief beach associates retain their prominence here. Cnicus Pitcheri occurs frequently, but chiefly at the lower level; Euphorbia polygonifolin and Enothera biennis were observed but rarely and only at the lower level; Lathyrus, Corispermum, and Agropyrum were not found at all. In place of these upper beach plants the Artemisias have a new crowd of associates. In general the terraces and fossil beaches have four dominant character plants, Artemisia Canadensis (or $A$. caudata) as already named, Solidago humilis Gillmani, Lithospermum hirtum and Andropogon scoparius. Solidago and Lithospermum were noted as occurring at times on the upper beach, but they are far more common here. Andropogon was not observed on the true beach, but is very common on 
fossil beaches and terraces, its scattered bunches or tufts forming one of the chief landscape features.

On the more northern fossil beaches several species are almost as characteristic as those named in the preceding paragraph. Prominent among these forms are Zygadenus elegans, Campanula rotundifolia arctica, and Arenaria Michauxii; northward these types are almost wholly confined to the fossil beaches or terraces, although Zygadenus is sometimes present on the upper beach. Anemone multifida, Keleria cristata (?) and Arabis lyrata occur northward but are less frequent. A very interesting plant which sometimes frequents fossil beaches is Hudsonia tomentosa, a species noted for its habit of forming scattered clumps of densely tufted growths. Other occasional tenants of the terraces and fossil beaches are Populus monilifera, Prunus pumila, Calamagrostis longifolia, and Solidago nemoralis.

While the fossil beach looks backward to a true beach history, it commonly looks forward to a heath. Largely protected from the accumulation of sand, they furnish a situation favorable for the development of a juniper-bearberry heath. Such heaths are in process of formation at Manistee, North Manitou and elsewhere, and will be described in another place.

\section{$B$. THE EMBRYONic OR STATIONARY BEACH DUNES.}

\section{Dunes of rapid growth (primary embryonic dunes).}

Many of the lake winds which blow across the beach have a surplus of energy, and are able to select out the finer grains of sand and carry them farther from the shore. The action of the wind in transportation is analogous to that of water. The finer particles are picked up bodily by the air currents, while the larger particles are blown or rolled along on the beach. Whenever an obstacle is met, some or all of the load is necessarily deposited by the wind. The coarser particles are deposited upon or about the obstacle, while the finer particles form a diminishing trail on the lee side. As soon as the deposition is sufficient to relieve the overladen wind, the trailing of sand ceases, and the wind continues
with its lessened load until another obstacle is reached. So long 
as the wind blows cuntinuously from one direction, the mound of sand keeps growing and the trail to the leeward becomes more and more conspicuous. Indeed, the growth increment is often greater during the later stages of a continuous wind current, since the growing mound of sand becomes more and more an obstacle to the progress of the laden wind. As a result of this action, there appears a topographic form with a steep windward side and a gently sloping leeward side.

When the wind changes, the trails of sand are no longer in the lee of the obstacle, but are more or less exposed to the wind, and hence are rapidly removed. The contour of the mound is changed and there results, just as before, a topographic form, steep to the windward but gently sloping to the leeward. It will thus be seen that it is always possible in dry weather to determine the direction of the last sirong wind by observing the position and direction of the leeward trails of sand. A clump of grass with a poorly developed leeward trail may be seen in the foreground of $f i g$. 4 .

Under ordinary conditions no permanent results follow from such wind action as has been described, since one wind destroys the products of another. There is, perhaps, a tendency for sand to accumulate on the landward side of obstacles, since the energy of the lake winds is likely to be greater than the energy of winds from other directions. But no extensive dune formation can occur on the beach, unless the obstacle, which compels the wind to deposit its load, is itself increasing in size. A mound of sand, which is being built up by the wind, becomes more and more a formidable obstacle to the progress of the sand-laden currents, and it might be supposed that the growth of such a mound would continue indefinitely. Such does not appear to be the case on the beaches studied. The wind blows over the beach from so many directions and with such resistless energy that mounds of sand rarely accumulate without the aid of other factors.

The formation of beach dunes, then, depends upon something more than wind and sand. An obstacle is needed which will 
grow pari passu with the dune, and such an obstacle is furnished by a number of perennial plants, which spread by means of rhizome propagation. These dune-forming plants must be perennials; otherwise the dune would be destroyed at the end of the growing season. Such annual dunes are very common on the beach. Clumps of Cakile have been seen, about which there is piled a miniature dune. In the same manner there may be formed biennial dunes about individual plants of Artemisia or Cnicus. A perennial dune, however, requires perennial duneformers. A second necessity in a dune-former is the ability to spread radially by rhizome propagation, for only in this way can the area of the obstacle and the area of the dune be enlarged. The only notable exception to this rule is found in the case of cottonwoods and such perennial grasses as Andropogon and Elymus; these plants grow in groups or tufts and will be described later.

The plant which serves as an obstacle for the wind must also possess the power of growing out into the light when buried by the sand. This property permits the rise of the dune in altitude, as rhizome propagation permits the increase in area. Most plants are excluded by reason of this third requirement, partly because they are unable to rise above the sand when buried, and partly because stem elongation increases the difficulty of drawing up a sufficient supply of water from the soil. The roots of dune plants are often uncovered and exposed to wind and sand-blast action; hence plants unable to survive a period of root exposure cannot live in such a habitat. In short, a successful dune-former must be able at any moment to adapt its stem to a root environment or its root to a stem environment. The vicissitudes of existence on an embryonic dune are greater than anywhere else, except at a few points on the dune-complex. In addition to the above particular requirements, a dune-former extreme xerophytic adaptations. Nowhere else except on the

beach is there so great exposure to heat, cold, and wind. 


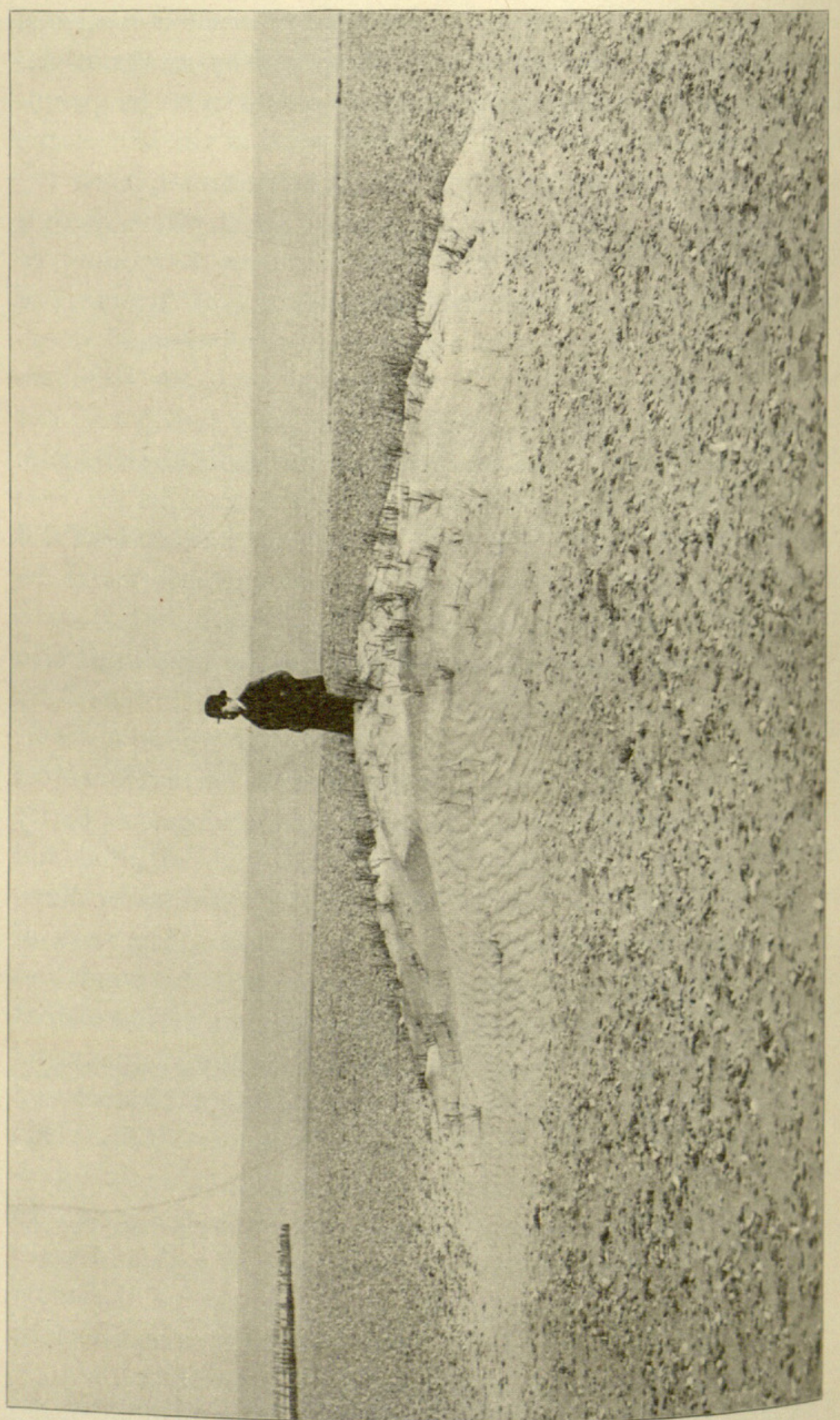




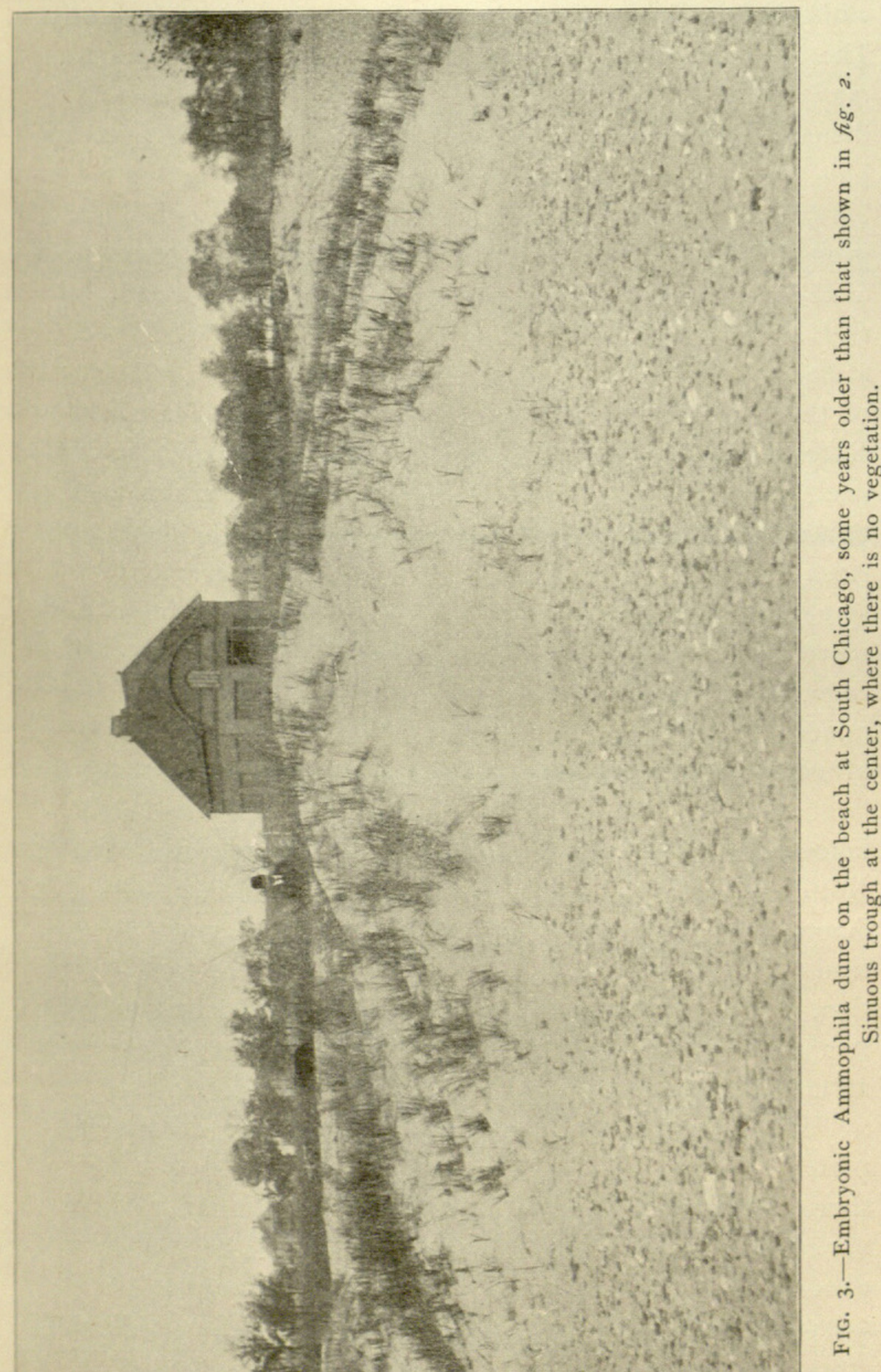


along Lake Michigan is the sand reed, Ammophila arundinacea. The life history of an Ammophila dune will now be given, and may be taken as the average life history of a stationary beach dune. Whenever a tuft of this or any similar grass gets a foothold on the upper beach, the sand drifts along and is lodged in between the stems and leaves, as already described (see foreground, fig. 4). The leeward trail of sand changes its position as the wind varies its direction, but the sand deposited between and around the blades of grass is not easily dislodged. The radial propagation of the tuft of grass causes an areal extension of the miniature dune. So, too, there is an increase in altitude, since the grass constantly grows higher in its endeavor to lift itself above the sand. This upward growth enables more sand to accumulate; in other words, the grass and the dune grow pari passu outwards and upwards. The result of several years of this symbiotic growth of dune and grass may be seen in fig. 2, which represents a small embryonic dune on the beach at South Chicago, Ill. The general contour of the dune is seen to be determined by the Ammophila; toward the left is the leeward trail of sand left by the last wind. Fig. 3 represents an older and larger Ammophila dune on the same beach, viewed from the lakeward side and hence not showing any leeward trail of sand. Not only is the general contour of this dune determined by the Ammophila, but there will be observed a somewhat sinuous trough toward the center, where there happens to be no vegetation. This shows how readily the dune would be removed were it not for the plant life present. Thus Ammophila is not only an efficient dune-former but also a dune-holder.

While Ammophila is the most common dune-former and perhaps the best adapted for that difficult task of all our lake shore plants, many other species play a similar rôle. On the northern beaches Agropyrum dasystachyum is very common as a dune-former; its habit is exactly that of Ammophila, and consequently needs no description. Elymus Canadensis and Calama grostis longifolia may be regarded as dune-formers, but they are of less importance than Ammophila and Agropyrum. A 


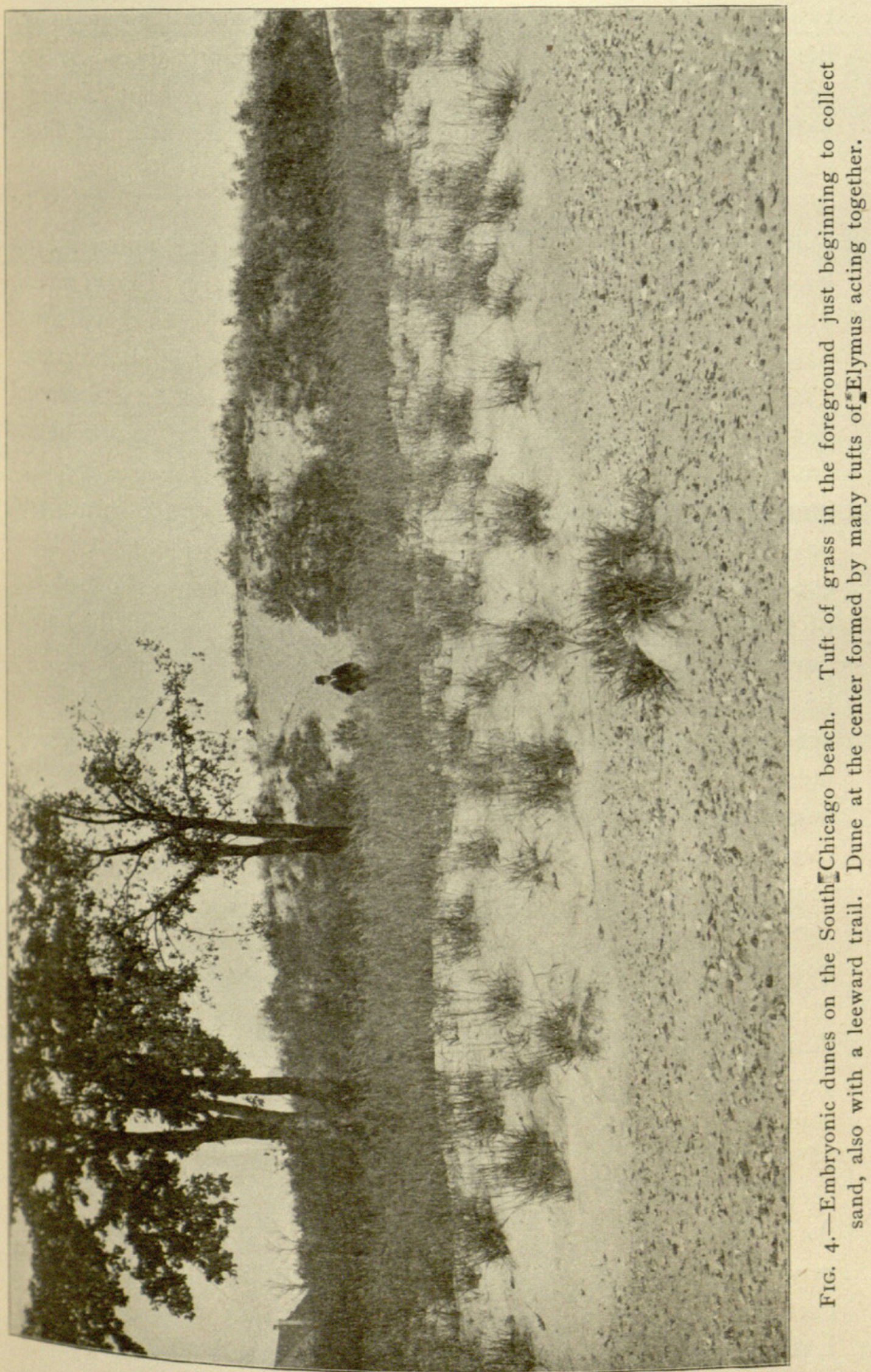


typical Elymus dune, as found on the South Chicago upper beach, is represented at the center of $f g .4$. These grasses grow in tufts and do not have any extensive vegetative propagation, but the tufts may be so close together as to act like a large social clump of Ammophila.

Certain shrubs are of almost equal importance as dunebuilders with the grasses. Among these, the willows, Salix adenophylla and S. glaucophylla, and the sand cherry, Prumus pumilh, deserve especial mention. All of these shrubs have social habits, and rapidly increase their area of control in all directions. The willows are particularly well fitted to build up a perennial beach dune. They are about as well adapted to a xerophytic environment as are any of the grasses, and their vegetative increase is about as rapid. The fact that they are shrubs and have a greater power of vertical stem elongation makes them even better fitted to rise above the sand. When a shoot of one of these willows is buried, roots are sent out from all the buried portions, even up as far as the floral axis. The willows, too, can be uncovered without suffering serious injury. In short, the species of Salix are able to adapt their stems to a root environ. ment, or vice versa, better than any other plants found along the coast. Hence the willows stand abreast of Ammophila as duneformers. Another shrub that seems to have all the necessary requirements for a dune-builder is Cornus stolonifera (or $C$. Baileyi), though it is probably less fitted for a xerophytic life; however, Cornus dunes are by no means rare on the beach.

The only trees which make any significant contribution to dune formation are the poplars, Populus monilifera and P. balsant fera. Of these, the former is the more important, especially southward. These trees have little or no vegetative propagation of the willow type. Every year great numbers of cottonwood seeds germinate in protected depressions on the upper beach. As the young plants grow rapidly, it is not long before they form groups dense enough to retard the sand-laden winds. Thus a cottonwood dune is formed, a type which characterizes the Lake Michigan shore at very many places. A cottonwood dune 


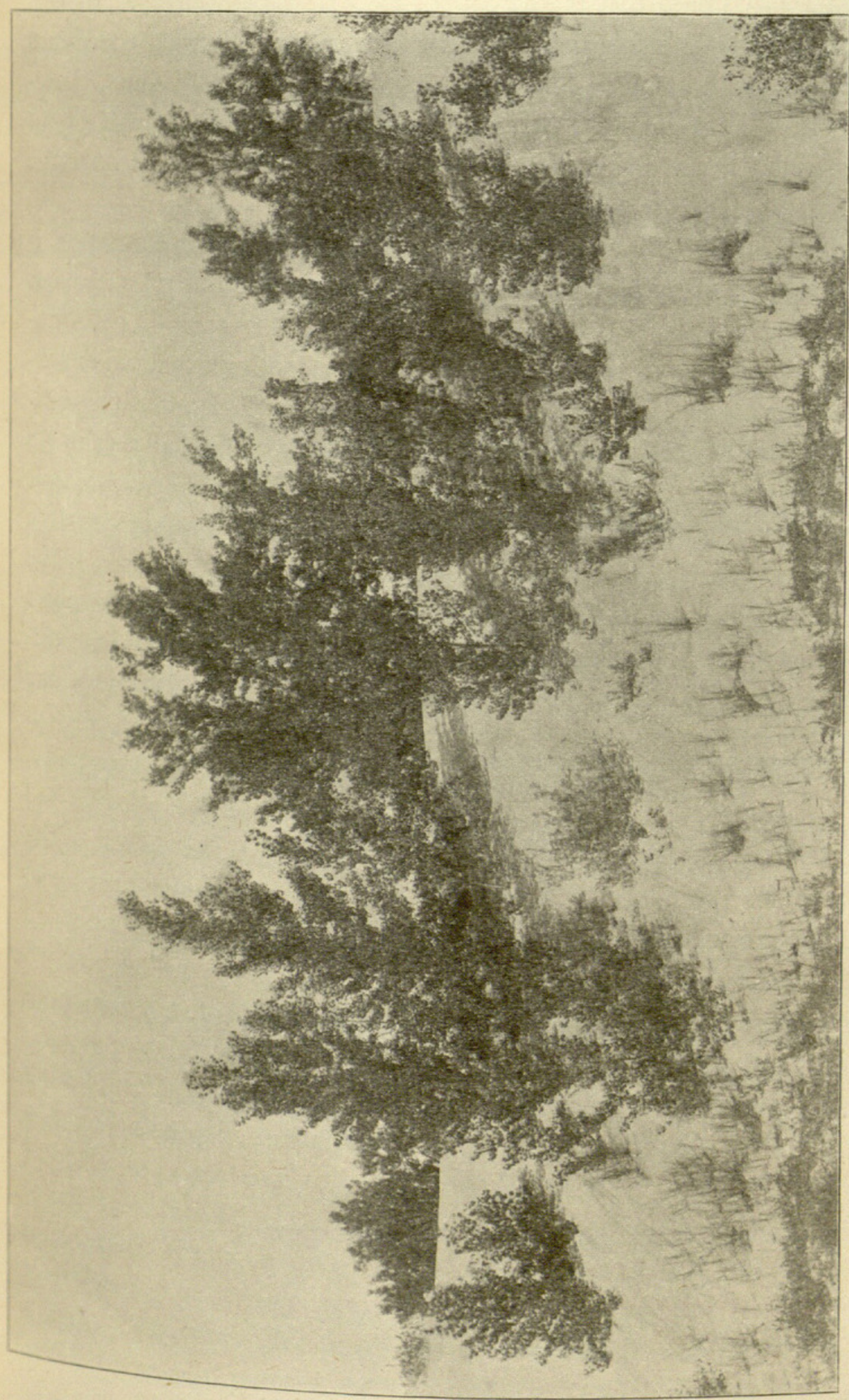

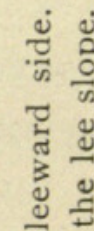

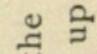

+ 里

हี ญ

$\tau$ 요

赵

익

$\therefore$ 宓

iे

हे पे

(2)

층

(a)

ปี

s.

वं

ซึ क्ञ

$\circ \%$

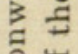

$\stackrel{3}{3}$

$\circ \stackrel{0}{8}$

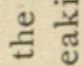

is

ग)

है

둘

त $\frac{3}{0}$

i.

ฏ ำ

눙

तै

ะ

ปั

ह

है

되

1 굴

in

อ อี

I

$+4$

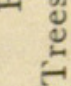


a number of years old is shown in $f i g .5$. It is possible to see, even from the photograph, that the lower portions of the trees are covered by the sand. The growth of a cottonwood dune, therefore, is of a symbiotic nature, exactly as is the growth of an Ammophila dune, in spite of the great difference between the life habits of these two dune-formers.

The controlling part which plants play in dune formation is still further shown by the variations among the embryonic dunes as to area, shape, and height. Dunes that are formed by Agropyrum, Ammophila, or Salix are capable of indefinite areal expansion, since these plant types have extensive vegetative propagation. Populus or Elymus dunes, on the other hand, always retain essentially the same area, since there is little or no vegetative reproduction, and since the opportunity for any further development of seedlings is removed. Young seedlings are often found in the moist sand of the depressions, but never in the dry sand of the dunes. The Agropyrum dunes are always very low, seldom if ever a meter in altitude. The Ammophila dunes are higher because this latter plant type has a greater power of upward growth than has the former. Both the Agropyrum and Ammophila dunes are alike in being relatively large and low, with slopes almost as gentle as those of the beach. The Salix dunes are equally large, but higher and steeper because of the greater power of upward growth. The Prunus dunes are very small because of the slight vegetative propagation, and yet they are relatively high and steep because of the pronounced power of upward growth.

The cottonwood dunes are the highest of all, often having an altitude of several meters, because the cottonwoods groff higher than any other dune-former; they are also the steepest because there is no vegetative propagation. The steep slope of a cottonwood dune is shown in fig. 5; the marks in the sand at the right are the paths made by the movement of the sand dowt the steep slope, and indicate a gradient of about $30^{\circ}$. Figs. 2 and 3 indicate the gentle slope of the Ammophila dunes. The cottonwood dunes are commonly long ridges parallel to the lake 
shore. This is partly due to the fact that the depressions in which the seeds germinate are parallel to the shore, because of wave action. The prevalence of lake winds perpendicular to these ridges also helps these topographic forms to retain their original shape. Summing up this matter, then, the area of a beach dune is determined chiefly by the amount of the vegetative propagation of its tenants, the steepness is determined by the rapidity of this propagation, and the altitude by the power of the dune plants to increase in height.

Of the dune-forming species, Ammophila arundinacea and Salix adenophylla are the most abundant, occurring almost everywhere that beach dunes exist. These two species are most at home when half-buried in the wind-blown sand, and occur much less frequently in other associations. Prunus pumila and Calamagrostis longifolia occur throughout the region, but are less characteristic of the beach dunes than are the first-named species. Prunus is common on the upper beach, as already shown, and also on the heath; Calamagrostis is particularly characteristic of the larger active dunes. Agropyrum dasystachyum is very common at Glen Haven and farther north, and, like Ammophila, is most at home on the beach dunes. Populus monilifera is very common farther inland than the other types. This species is replaced northward to some extent by Populus balsamifera and its variety candicans (both sometimes on the same tree!), though this poplar is much less of a dune-former than the cottonwood. Salix glaucophylla is frequent on the beach dunes, especially southward,
but is more but is more characteristic of the swamps; the same may be said
of Cormus of Comus stolonifera. Elymus Canadensis is not abundant anywhere on the beach dunes.

An interesting corollary may be deduced from the last three in the life habits of the dune-forming species, it follows that the distribution of certain topographic forms coincides with the distribution of the dune-formers. Low dunes of the Agropyrum type are not found at the south end of the lake. The steep ridgelike
. Low dunes of the Agropyrum type 
cottonwood dunes are common southward, but rarer north. ward, since cottonwoods are rarer northward. This is only one of the many cases where ecology helps to interpret physiography.

The dune-forming plants are not the only tenants of the beach dunes. Most of the species that grow on the upper beach are also frequently present on the dunes. Those of especial importance are Artemisia Canadensis (or A. caudata), Cnicus Pitcheri, Lathyrus maritimus, Euphorbia polygonifolia, and Corispermum hyssopifolium. By reason of its extensive vegetative propagation, Juncus Balticus littoralis sometimes serves as an obstacle to sand-laden winds, and by a limited subsequent growth results in the formation of miniature dunes. Lithospermum hirtum, though more characteristic of embryonic heaths and rejuvenated dunes, sometimes ventures out upon the beach dunes. It should be likewise noted that any of the dune-forming species are likely to grow on dunes that are formed in the main by others, although the vegetation of individual embryonic dunes is often composed of a single species.

Though no plant formation anywhere can have a much larger percentage of plants that are entirely independent of other plants, the beach dunes, nevertheless, have occasional forms that are parasitic, saprophytic, or epiphytic. Various unidentified Basidiomycetes have been found in the most open places, deriving their nutriment from buried driftwood. The most notable parasite found was Aphyllon fasciculatum, a plant which derives its nutriment through attachment to the roots of Artemisia. Lichens are abundant on the cottonwoods at all places that are not directly exposed to a fierce sand-blast action. Common lichen species in such places are Physcia stellaris, Thelosclisters concolor, and Placodium sp.

Interesting beach dunes were seen on the shores of two small inland lakes, Crystal lake, near Frankfort, and Fount lake, on Beaver island. In each case the lakes approach a dune area near the shore of Lake Michigan, suggesting the probable origin of the sand; there can be no question, however, but that the sand composing these beach dunes was washed up by the waves of 
the small inland lakes and worked over by the winds, exactly as described in the preceding pages. The dune-forming winds at Crystal lake are easterly winds, chiefly because the source of sand is on the west side of the lake, and it is on the west shore that the dunes are located. There are typical Ammophila dunes at this point. Among the other plants growing here are Artemisia, Cnicus, Populus, Cornus, Prunus, Lathyrus, Enothera, Corispermum, Calamagrostis, Elymus, and Juncus. At no place on Lake Michigan was a more typical and varied beach and beach dune flora observed than on the west shore of Crystal lake.

\section{Dunes of slow growth (secondary embryonic dunes).}

Dune formation is by no means confined to the upper beach, but may take place anywhere that the sand is able to collect, provided the plants at that place are fitted to be dune-formers. The formation of dunes on the dune-complex and on rejuvenated dunes is essentially like that on the upper beach, and will be discussed later. New dunes of a very interesting type are in process of formation on many fossil beaches and on the gravel terraces. As has been previously stated, the terraces and fossil beaches are better protected from the wind than is the upper beach, and there is in consequence not only a more luxuriant flora, but also a different plant assemblage. The sand which blows across these places, though less in quantity and less furiously driven, nevertheless is capable of dune formation if the proper plant species are present. Several of the beach duneformers also occur on the terraces and fossil beaches, and build up small dunes. Among these are Ammophila, Calamagrostis, Prunus, and Populus.

Among the dune-formers on terraces and protected fossil This grass grows in tufts and is very abundant, as has been already stated. About each tuft a mound of sand has often collected. A photograph showing the striking appearance of an area of Andropogon dunes was unfortunately spoiled, but its appearance is much like that of an area of roches moutonnées, as 
figured in geological works. Hundreds and sometimes thousands of these miniature dunes may be seen in a single landscape. Arctostaphylos Uva-ursi and Juniperus Sabina procumbens are duneformers within moderate limits. Both of these shrubs are procumbent creepers, and hence unable to rise above the sand to any considerable height, probably never as much as a meter above their original position. It is for this reason that such hardy plants as these cannot grow successfully on an upper beach that is exposed to extensive sand drifting. The above three species are the most prominent dune-formers in protected places. Arctostaphylos dunes occur throughout, and are not confined to fossil beaches, but are also common on exposed heaths. The Andropogon dunes were not seen except on fossil beaches, although this grass is common along the entire coast. The Juniperus dunes occur chiefly northward.

The dune formation seen on east coasts was chiefly of this small, slow-growing, secondary type. The dunes at Waukegan, in part at least, are formed by Juniperus. On the east shore of Beaver and North Manitou islands, there are a number of low dunes formed conjointly by Juniperus and Arctostaphylos. There are low slow-growing Juniperus dunes on the shore of Fount lake on Beaver island; in addition to the procumbent juniper, Juniperus communis and Gaylussacia resinosa assist in dune building here. The Andropogon dunes are better developed on the fossil beaches of North Manitou island than at any other point visited. On these same fossil beaches, Hudsonia tomentosa serves in a small degree to collect the wind-blown sand. On the east shore of North Manitou island, the pasture grass, Poa compressah forms miniature dunes.

Near the beach at South Chicago there are swampy depressions tenanted by Potentilla Anserina and Polygonum Hartwrigltit plants which are best developed in low grounds but which oftel creep up to higher levels. On these higher levels near the beach they collect the drifting sand and are able to form low dunes, similar to Arctostaphylos. These plants show a most surprising plasticity, since a single individual developed in a swamp is able 
to adapt itself to a mild type of dune existence. Another swamp plant, Cephalanthus occidentalis, occurs near the same beach and in a similar way helps to build these low slow-growing dunes. The conversion of swamp plants to dune plants will be discussed more at length in another place.

The most extensive area of dune formation on the beach was seen on the west shore of Beaver island. Fig. 6 shows a

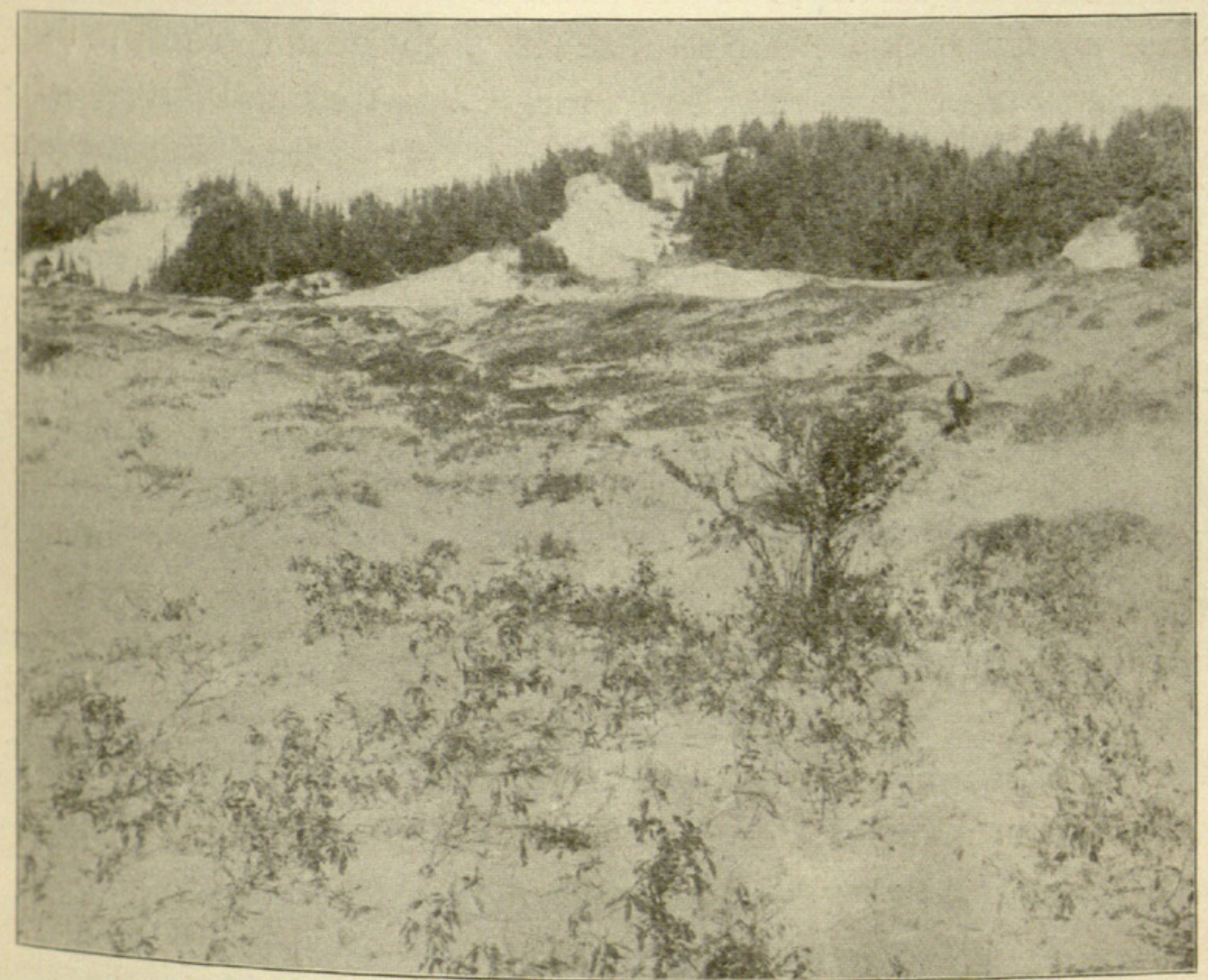

FIG. 6.-Embryonic beach dunes at Beaver island. Primary Prunus and Salix dunes in the foreground. Secondary Arctostaphylos dunes superposed on primary thes, at the center of the picture. Old lines of established coniferous dunes in the background, becoming rejuvenated at several points,

small portion of this area. This place is of peculiar interest because there is a perfect series of gradations between the rapidly growing dunes first described and those of the slower growing type. Toward the beach proper (foreground, fig. 6) there are dunes formed by Salix, Prunus, and other high-grade dune-builders. Farther back, toward the taller and older dunes
and 
of a previous epoch, there may be seen low dunes built by Arctostaphylos, Juniperus, and Potentilla fruticosa, small dune excrescences on a general dune substratum. The life-history of these dunes appears to have been as follows. First a stage of dune formation by such plants as Salix, then, as vegetative propagation allowed these plants to encroach more and more lakeward upon the broad beach, new dunes were formed nearer and nearer the lake. Or, perhaps, there was a recession of the lake and a consequent extension of the beach into new territory; these new dunes may have thus been formed farther and farther lakeward, keeping pace with the advancing shore line. In any event, the interposition of a new row of dunes between the lake and those first formed essentially changed the life conditions on the latter. The row of dunes nearest the lake serves as a windbreak. The first row catches most of the drifting sand, and the second catches most of what remains. This fact makes it possible for the slow dune-formers to inhabit the more inland of the ridges. Expressed in other words, the high-grade or primary embryonic dunes encroach upon the lake, not by the actual advance of an individual dune in that direction, but by the formation of new ones; in like manner the low-grade or secondary embryonic dunes encroach upon the former type, using the topographic form of the primary dune as a base of operations, and building new dunes as low excrescences upon the old.

The advance of a dune area toward the lake, as just described, shows how the coastal belt of dunes may grow wider as the years pass by. In another place it will be shown how they may also grow wider by the actual advance of an individual dune upon the land. In concluding the section on the embryonic dunes, it may be well to emphasize in another way the radical difference between the two types that have been discussed. Their intimate gradation, as shown at Beaver island, is by no means the universal fact. Perhaps it is even more common for one of the primary type to leave its original habitat and wander across the country as an active dune. The secondary type never has that history; an Arctostaphylos dune almost always grows into a heath. 
C. The aCtive or WANDERing DUnes. THE DUne-Complex.

\section{Transformation of stationary into wandering dunes.}

The symbiotic growth of the beach dunes and their builders may go on for years, but a prolonged existence of these relations is unlikely. As the mounds get larger and higher the conditions for further accumulation of sand become, if anything, more favorable. It is not so with the plant tenants, for each year they are raised farther from their chief base of supplies, the water level. It is probable, also, that the desiccating influence of radiant energy and wind upon the aerial organs becomes greater and greater as the years go on, because of greater exposure at the higher levels. Again, the dune-formers, although perennials, do not have an indefinite duration. The life cycle of the cottonwood is relatively short for a tree. All of the other prominent dune-formers spread more or less by vegetative propagation, so that it is difficult to determine a definite life cycle. Even though an existence of indefinite duration might be secured through vegetative propagation, many individual shoots must die in the course of time.

In one way or another, then, dune formation ceases and another phase of dune history begins. There is here an end of the stationary beach dunes, a beginning of the wandering dunes. When the plants are no longer able to oppose its progress, the first effect of the untrammeled action of the wind is seen in a tendency to reshape the topographic forms. The beach dunes heretofore described are more or less symmetrical, because of the tendency toward symmetrical plant growth. A dune fashioned entirely by the winds without the assistance of plants is never symmetrical. The windward slope has a very gentle gradient, usually about $5^{\circ}$, and because of the destructive action of the wind, this slope is topographically rough and uneven. The leeward slope, however, is much steeper, averaging about $30^{\circ}$, and is very smooth and even, because determined by gravity instead of wind. The wind sweeps up the gentle windward slopes, blowing or rolling the sand along until the crest is reached; here the 
sand is deposited by the wind and it rolls down the steep slope, spreading itself quite evenly. Fig. $I_{7}$ shows an average gentle windward slope, figs. 13-15 steep leeward slopes.

The Prunus dunes are particularly favorable for a study of the origin of an active dune, since their form is most at variance with that of the wind-shaped dune, as described above. A Prunus dune is commonly a low cone more or less rounded at the top. As soon as the plants are dead, and sometimes long before that event occurs, the wind endeavors to reduce the windward gradient by removing the sand toward the top and blowing it over on the other side. In this way the roots are exposed and existence made less endurable, if the plant is still living. Prunus dunes with roots exposed on the windward side are common at Dune Park, Beaver island, and elsewhere. On the terrace at Glen Haven, some dunes have been carried beyond their former resting place, leaving the scraggy clumps of Prunus roots at the rear.

What has been said of the Prunus dunes holds more or less for the other types. The cottonwood dunes especially are peculiarly subject to the destructive attacks of the wind, since their shape also notably fails to correspond with that of a normal wind-made topographic form. The lower Ammophila, Salix, and Agropyrum dunes are less likely to suffer destruction, and yet small Ammophila dunes were seen on the dune-complex at Glen Haven that had been blown away from their first abode. leaving the Ammophila stranded at the rear. Even while living, these dune-formers were unable to hold the dunes which they had helped the wind to build; much more when dead are they likely to have the dune swept on beyond them.

The destructive action of the wind and the transformation of a stationary into an active dune are very much retarded by the tenacity with which the stems and roots retain their place, even when dead. A plant which thus has the power to hold its position and keep the sand from being blown away is commonly called a sand-binder. In this connection it may also be called a dune-holder, as it has been already called a dune-former. 
Perhaps the most tenacious of all the dune-holders on the coast of Lake Michigan is Calamagrostis longifolia. This grass, as has been seen, is not of first importance as a dune-builder, but when it has once built up a dune it seems almost impossible to dislodge it. At the left of the basswood tree in fig. 23, there is shown a clump of Calamagrostis directly facing the prevailing wind at the summit of a mound, and stubbornly holding its position. The leaves, stems, and roots are all stiff and wiry, almost perfectly resisting the mechanical action of the wind. The roots in the sand form a network so dense that it is almost impossible for the wind to remove the sand from among them.

From an economic standpoint, Ammophila arundinacea is a more successful dune-holder than is Calamagrostis, but its greater success is due to its extensive vegetative propagation. The dense social growths of Ammophila make it difficult for the wind to get a start in the process of sand removal, whereas the sand can be readily picked up from between the more scattered tufts of Calamagrostis. An individual tuft of the latter, however, seems to be much more resistant than a tuft of Ammophila. Calamagrostis, too, grows in more exposed situations than does the other grass, and hence is a valuable dune-holder in places where Ammophila might not thrive at all.

Another noteworthy dune-holder is Prunus pumila. A very common sight on the upper beach is a truncated cone literally covered at the summit and sometimes on the sides with a dense has ref dead stems and roots of the sand cherry. The wind wait until the all the sand which it can reach and is obliged to wind to blow thems and roots decay sufficiently to allow the is one of the first plants get at the sand beneath. Prunus process of dune formation to succumb before the dune in the short, but more probably the process of drawing up water a
greater and greater up the unequater distance each year compels the plant to give Sooner or struggle.

are all rem or later the dead roots and stems of the dune-holders all removed, and the wind becomes the undisputed master of 
the situation. If there is a sufficient amount of sand still remaining, the once stationary dune begins to move, not bodily, of course, but none the less steadily and surely. The sand is swept up the low gradient of the windward side, deposited at the crest, and carried down the steep leeward slope by gravitation. In this manner successive parallel layers of the windward slope are carried over the crest, and the dune as a whole advances inland. The simple life-history just outlined is the exception, not the rule. Much more commonly the sand is scattered in many directions, collecting wherever new lodging places can be found. These processes of deposition and removal, dune formation and dune destruction, are constantly going on with seeming lawlessness. However, in the district as a whole the sand is constantly increasing in quantity, whatever may be true of the individual dunes here and there. The outcome is certain to be a wandering dune in the process of time, unless the actions of the wind and wave are checked. Because of the complexity of the conditions when the movement across the country becomes a conspicuous fact, it seems well to apply the term dune-complex to the totality of topographic forms which make up the moving landscape as a whole.

\section{Physical and biological features of the dune-complex.}

It will not be necessary to trace farther the changes involved in the transformation of simple beach dunes into a dune-complex, although the coast of Lake Michigan shows all of the intervening stages. Inasmuch as a single dune-complex illustrates almost all conceivable conditions of a dune's life-history, a careful description of a typical dune-complex will involve all of the essential points. The dune-complex is best developed at Glen Haven, Mich., and Dune Park, Ind. All of the essential features are present in both areas, though developed on a grander scale at Glen Haven. The Dune Park area has been most carefully studied, and most of my photographs were taken there.

The dune-complex is a restless maze. It is a maze because all things that a dune ever does are accomplished there. While 
there is a general advance of the complex as a whole in the direction of the prevailing winds, individual portions are advancing in all directions in which winds ever blow. It is not at all uncommon to find small dunes advancing over the dune-complex back toward the lake. At Dune Park the main line of advance is southeast, yet some small dunes advance toward the northwest, because taller dunes are situated between them and the lake. These little dunes in the lee of large ones are protected from the westerly and northerly winds but feel the full force of the easterly and southerly winds, and hence advance contrary to the prevailing direction. It is thus a common sight to see two dunes advancing to meet each other; when they come together, of course the two dunes become one and move in the direction of the prevailing winds. From this account it is easy to see that small dunes on the complex may advance in any direction, provided only that they are protected from winds blowing in other directions.

The dune-complex, however, is much more than a maze of little dunes wandering in all directions. At many points there are to be found the stationary embryonic dunes that have been previously described. All stages of their life-history may be seen; the beginning, the climax, the destruction. Here and there the wind sweeps out great hollows, which reach down almost to the water level. Great troughs are carved out by the wind, chiefly at right angles to the lake, but also at all other angles. Here and there vegetation has obtained a foothold on the complex, thus converting portions of it into an established dune. These established dunes may become rejuvenated, or the vegetation may spread until it covers large portions of the complex. The most striking feature of the dune-complex, then, is its topographic diversity.

To one who visits a dune-complex season after season, another feature comes to be as striking as its diversity, and that the same, a barren scene of monotony, but the details are never

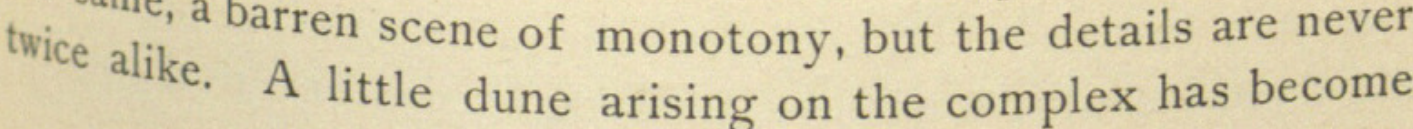


enlarged, another has passed from existence without leaving a trace behind. Where a dune was advancing last year, there is now, perhaps, a hollow swept out by the wind. Where last year was a hollow there may now be seen the beginnings of a flora, or again the flora of a former year may have been buried out of sight. The dune-complex, then, is not only a maze, but also a restless maze.

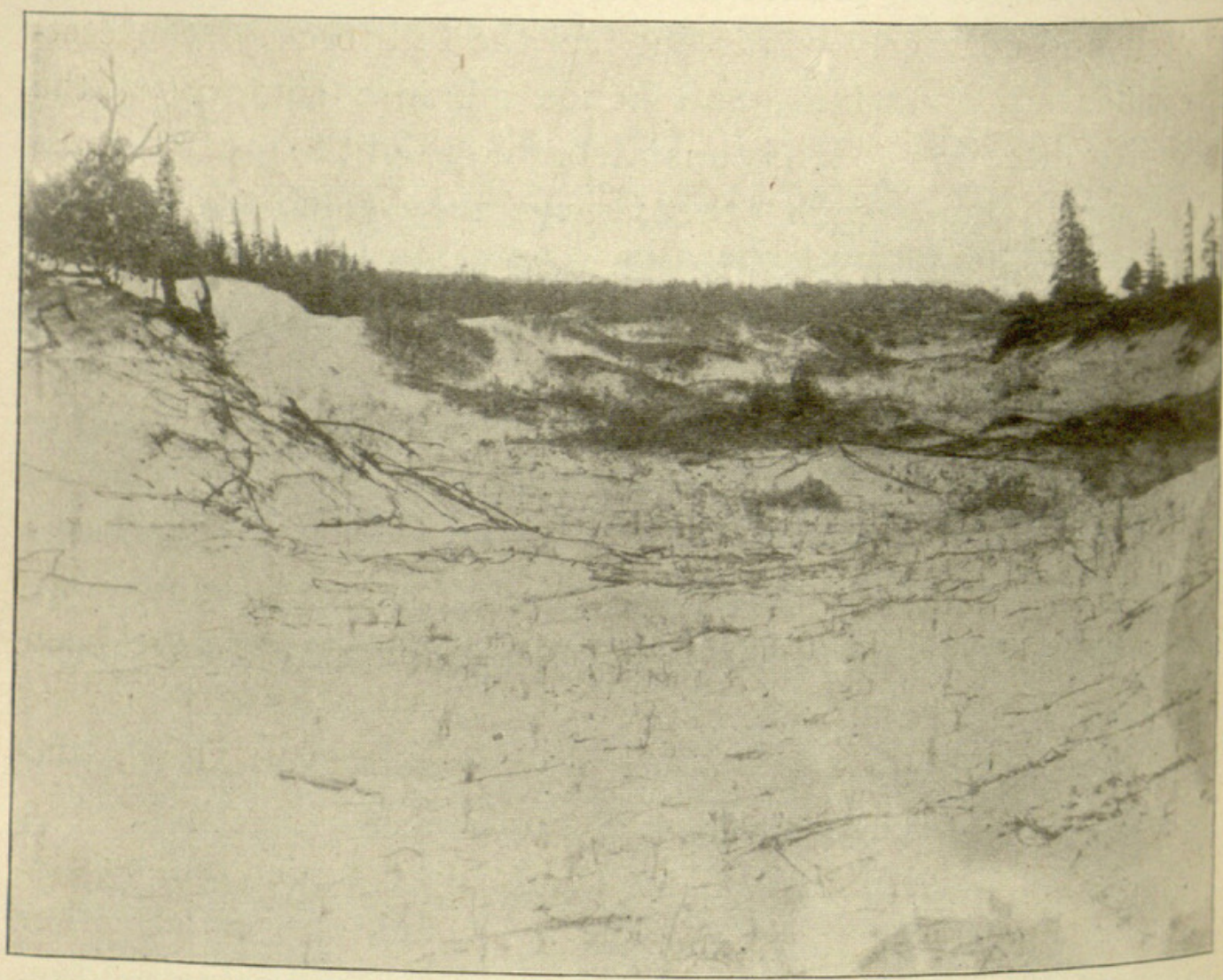

FIG. 7.-Trough-shaped wind-sweep at Beaver island. Dead roots and branches of plants that have been torn up. Embryonic dunes in the background formed of sand brought from the foreground. Sparse annual vegetation in the wind-sweep.

It might seem impossible to unravel the tangled threads of the dune-complex; it is, indeed, impossible to write the details of its history. There is, however, a simplicity in the complexity. While little dunes advance in all directions, the complex as a whole advances in the direction of the prevailing wind. While there are troughs at all angles, the main troughs are likewise in the direction of the wind. The complex is like a river with its 
side currents and eddies at many points, but with the main current in one direction.

It has already been stated that the windward slope of an advancing dune is very gentle, averaging perhaps about $5^{\circ}$. That portion of the windward slope up which the main wind currents pass is also trough-shaped and may be called a windsweep. Fig. 7 shows a small trough-shaped wind-sweep at Beaver island; the direction of advance is from the foreground to the background. In the path of the wind there may be seen dead branches, the remnants of a vegetation that has been swept away. In the background are small dunes which have been formed by sand carried along the trough by the wind. A windsweep more characteristic of the dune-complex is shown in fig. 17. Here, likewise, the prevailing wind direction is up the gentle slope away from the foreground. At this particular place there is in reality much more of a trough than is shown in the photograph, since there is a conspicuous rise both at the right and at the left. Just beyond the pines in the background there is a steep pitch downward, the advancing lee slope.

The most remarkable wind-sweep at Dune Park reaches down almost to the water level, appearing like a cañon, by reason of its steep sides from ten to twenty meters in height. This sweep, unlike most of the troughs, is curved so that a wind entering it as a northwest wind becomes a west and finally a southwest wind, and actually contributes to the advance of a dune toward the lake, as will be discussed more fully at another place in connection with fig. IO. The concentration of the wind energy which these gorge-like wind-sweeps permit is something remarkable. At no place is the destructive power of the wind upon deeper wind-sweeps. The foreground of fig. 22 shows the upper part of one of these troughs, and gives a vivid impression of the
wind's destructiveness.

The advancing lee slopes, as has been previously mentioned, exactly that at which sand, whose grains have the size and cohe- 
siveness there found, will lie. Figs. 9, $I_{3}, I_{4}$, and $I_{5}$ give some conception of the striking features presented by a landscape of which an advancing dune forms a part. Nowhere can there be a sharper line in nature, nowhere a more abrupt transition. The height of these slopes above the country on which they are advancing varies from almost nothing up to thirty meters at Dune Park. The Glen Haven dunes are far more imposing, since there is an almost unbroken line of advance for four kilometers, while the average height is from thirty to sixty meters above the territory on which they are encroaching.

The vegetation of the complex proper is exceedingly sparse. In the winter it appears almost a barren waste. The one plant which seems to be at home in all locations, whether wind-sweeps, exposed summits, or protected lees, is the bugseed, Corispermun hyssopifolium. This plant is an annual, and has been previously mentioned as a tenant of the beach and the beach dunes. The bugseed is shown in several of the photographs, but best in the left foreground of fig. I2. The seeds are winged and readily dispersed by the wind. Furthermore they germinate rapidy during wet spring weather. This power of rapid germination is a necessary condition of success, since the surface layers of sand dry off very quickly after the wet weather has ceased. The plants are obliged not only to germinate rapidly but also to send roots deep enough to reach beyond the surface desiccation. Even this perfectly successful plant species is often absent from large areas on the dune-complex, probably because of the difficulty which the seeds meet in finding lodgment. It is only an exceptional seed which is allowed to remain stranded on the complex, and many of the seeds which succeed in finding lodgment are likely to be buried too far below the surface to permit germination.

Another plant which deserves especial mention is the cottontwood, Populus monilifera. The plasticity of this species is remark able. Normally at home along protected river bottoms, it is yet able to endure almost all of the severe conditions of the dune-complex. Mention has been made of its importance as 3 


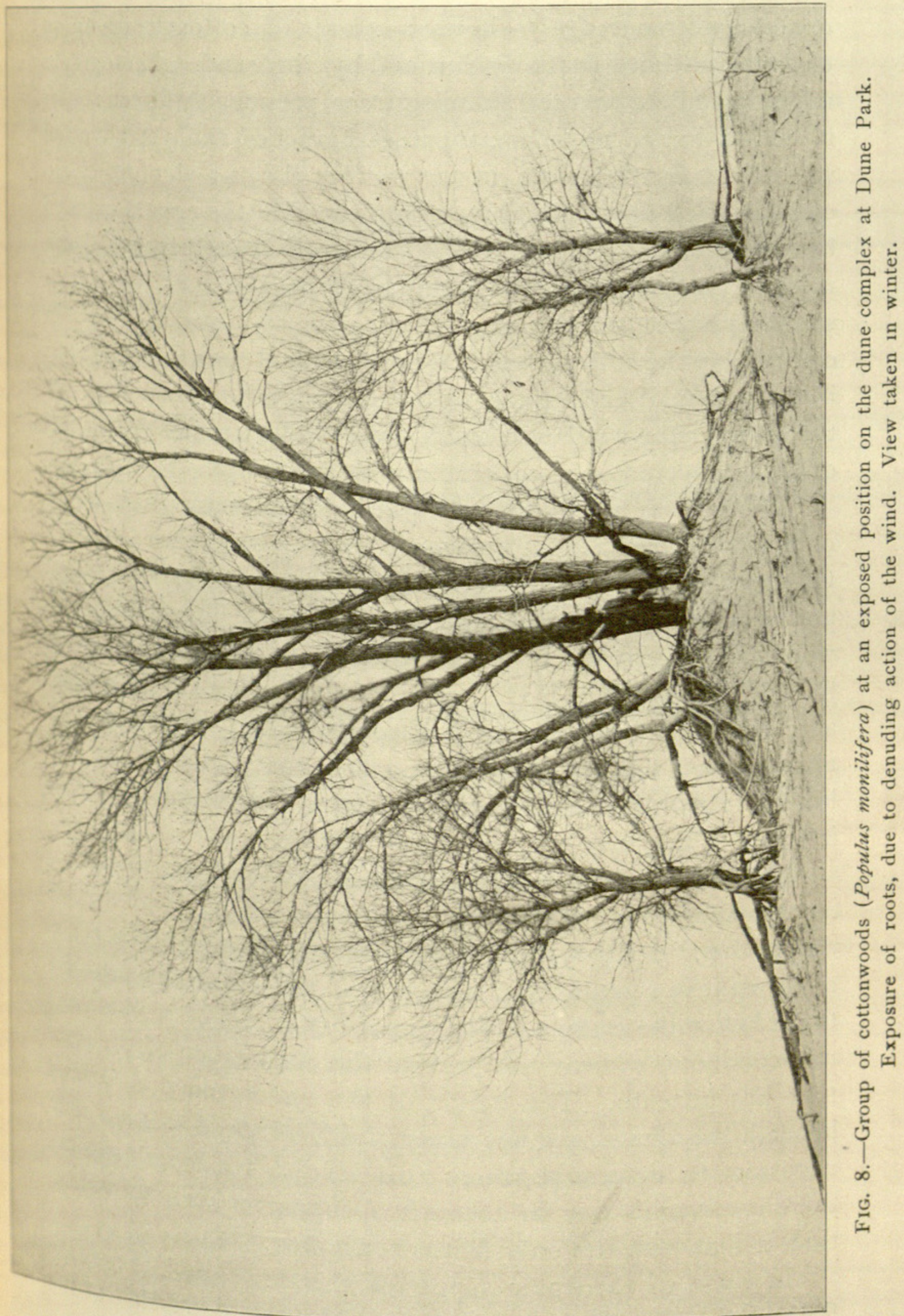


dune-former, and fig. 5 shows a group of cottonwoods on an embryonic dune partially buried by the sand. Photographs might have been secured showing trees, presumably fifteen meters in height, buried up to the topmost branches and yet alive and vigorous. Fig. 8 (taken in the winter) shows a vigorous clump of trees, high up on the dune-complex, with their roots exposed by reason of the removal of the sand from around them. Much more striking examples than this have been seen of living trees standing high up in the air, and yet with no apparent injury. In one respect the cottonwood is a hardier plant than Corispermum; it is a perennial and hence passes the winter on the dunes. In the summer the winds are much more moderate, and the chances of being covered or uncovered are more remote.

Two grasses are more or less at home at many places on the complex, Ammophila arundinacea and Calamagrostis longifolia. Of these the latter is the hardiest and most typical of exposed positions, such as shown at the left in fig. 23. The tenacity with which Calamagrostis holds its ground has already been mentioned. On the Glen Haven complex, Ammophila is particularly abundant. In some places it is so thick and green as to look almost like a field of grain from a distance; yet even here, the luxuriant growth is only in the protected places, and none at all is found in the most exposed situations.

The reasons for the scanty plant life on the exposed portions of the dune-complex are not far to seek. First of all it is not due to the scarcity of water in the soil. Even after a long period of drought in summer, the sand is cool and moist at a short distance below the surface. The upper dry layers of sand act as a non-conductor of heat and prevent the evaporation of the water that lies beneath. The height of the underground water level beneath the dunes was not ascertained. Indeed it is not at all necessary to determine, where this level actually resides, since there is enough water far above it to support a luxuriant vegeta. tion, if that were the only factor concerned.

In spite of the water supply in the dune sand, the scantly flora of the complex is characterized by the possession of the 
most pronounced xerophytic adaptations to be found in this latitude. These xerophytic structures will be discussed in the second part of this paper. At this point it is necessary only to state that in the main they are to guard against excessive transpiration, such as is induced by the unusual exposure to wind, heat, and cold. In a certain measure one might attribute these xerophytic adaptations to an insufficient amount of water in the soil, since, were they absent, the soil water would soon be used up. But it is much more important to discriminate, as ecologists are now coming to do, between conditions in the soil and those in the air. A plant may have its roots in the water and yet be exposed to a xerophytic air; in that case the aerial organs will be provided with xerophytic adaptations, as is the bulrush. Schimper, in his recent plant geography, goes still farther and calls some plants hygrophytic at one season and xerophytic at another. Perhaps the ultimate definition of a xerophyte will be a plant that is endeavoring to reduce its transpiration.

Directly or indirectly, the wind is the factor primarily responsible for the scarcity of vegetation on the dune-complex. Incidentally, as has been stated, the wind dries up the soil and increases transpiration. Incidentally, too, the mechanical action of the wind in connection with the sand-blast is destructive to vegetation. The cardinal destructive influence of the wind, however, consists in its power to cover and uncover the dune plants. Two plants have been referred to as peculiarly well adapted to dune life, Corispermum and Populus. The former is a small herb, and unable to endure either covering or uncovering to any great extent. This plant, however, is an annual of short duration and does not exist during the periods of the greatest
wind activity. The cottonwood, which has been shown to be best fitted to
withstand the instability of dune conditions, might be expected powers of endurance in all conditions of exposure; it may be to a depth of two or three meters, and yet flourish. Its failure 
to make any considerable headway on the complex is due partly to its relative inability to extend its area by vegetative propagation, partly to its short life cycle, and partly to the impossibility of germination. Thus a group of cottonwoods, which germinated when the conditions were more favorable and have been able to withstand the severe environment of the dune-complex, cannot appreciably extend their area, nor can they live for many years. New trees cannot take their place, because of the inability of the cottonwood seed to germinate on the higher exposed portions of the complex. These seeds sprout much more slowly than those of the bugseed, nor could the young plants withstand the winter conditions on the complex, even should they germinate. Furthermore, the likelihood of any considerable lodgment of cottonwood seeds is excluded by their light cottony appendages.

The University of Chicago.

[To be concluded.] 


\section{$2 \mathrm{BHL}$ Biodiversity Heritage Library}

Cowles, Henry Chandler. 1899. "The Ecological Relations of the Vegetation on the Sand Dunes of Lake Michigan [Continued]." Botanical gazette 27(3), 167-202. https://doi.org/10.1086/327812.

View This Item Online: https://www.biodiversitylibrary.org/item/94861

DOI: https://doi.org/10.1086/327812

Permalink: https://www.biodiversitylibrary.org/partpdf/222950

\section{Holding Institution}

Missouri Botanical Garden, Peter H. Raven Library

\section{Sponsored by}

Missouri Botanical Garden

\section{Copyright \& Reuse}

Copyright Status: Public domain. The BHL considers that this work is no longer under copyright protection.

This document was created from content at the Biodiversity Heritage Library, the world's largest open access digital library for biodiversity literature and archives. Visit BHL at https://www.biodiversitylibrary.org. 